Article

\title{
An Empirical Study of How Both Environmental Awareness and Interest in Artwork Can Be Incorporated into the Interior Design of Urban Hotels
}

\author{
Jeongah Kim ${ }^{1}$ and Eungoo Kang ${ }^{2, *}$ \\ 1 College of Engineering, Keimyung University, Daegu 42601, Korea; design1@kmu.ac.kr \\ 2 Business and Technology, DBA, Saint Mary's University of Minnesota, Minneapolis, MN 55404, USA \\ * Correspondence: exkang14@gmail.com
}

check for

updates

Citation: Kim, J.; Kang, E. An

Empirical Study of How Both

Environmental Awareness and

Interest in Artwork Can Be

Incorporated into the Interior Design

of Urban Hotels. Sustainability 2022,

14, 1005. https://doi.org/10.3390/

su14021005

Academic Editor: Michael S.

Carolan

Received: 25 November 2021

Accepted: 9 January 2022

Published: 17 January 2022

Publisher's Note: MDPI stays neutral with regard to jurisdictional claims in published maps and institutional affiliations.

Copyright: (C) 2022 by the authors. Licensee MDPI, Basel, Switzerland. This article is an open access article distributed under the terms and conditions of the Creative Commons Attribution (CC BY) license (https:// creativecommons.org/licenses/by/ $4.0 /)$.

\begin{abstract}
Prior studies on urban hotel service settings show that the positive response to the lobby artwork and interior design in a hotel is a performance determinant since it directly impacts the orientation of green customers' preferences who form a significant part of the primary and secondary consumers outcome of emotional satisfaction. In addition, it elaborates on the importance of marketing strategy based on hotel interior design for urban hotels intending to increase customer loyalty. For this reason, the present study collected a total of 330 South Korean participants to identify the mediating role of hotel lobby interior design and artworks between green customers' preferences and hotel loyalty. The survey instrument designed for the current study included 15 questions to test the hypotheses and a path analysis using AMOS 24.0 was conducted as the main tool to determine the relationship key factors. According to our statistical findings, it is acceptable to relate the customers' environmental awareness with interest in artwork in the hotel lobby due to the first impression created. The artwork gives a general perception of the value and quality that the consumer is likely to gain by interacting with the available products and services. It is also valid to indicate that the customers' environmental awareness closely relates to their preference for interior design to develop customer loyalty. Therefore, we conclude that the environmental awareness and hotel loyalty factors impact the marketing strategy and segmentation process used for the urban hotels that deal with green customers with unique and exclusive needs.
\end{abstract}

Keywords: urban hotel; hospitality; interior design; environmental sustainability; green customers; artwork; loyalty; environmental marketing strategies

\section{Introduction}

The environmental marketing strategy is an important decision-making tool in urban hotels that intends to attract and retain green customers with a high degree of environmental awareness. It focuses on the impact of the marketing method used when dealing with customers who are conscious of their environment and the value added by the services and products they consume from the chosen hotel brand [1]. The strategy ensures that the product concept and associated services are integrated into the marketing process and indicates that the outcomes cope well with the environmental trends in the current world [2]. Therefore, the designed and implemented marketing procedure is important because it addresses the exclusive needs and preferences of the green customers who maintain eco-friendly attitudes that do not affect negatively on environmental sustainability as they interact with the brand. The marketing strategy is significant since it focuses on the customers' interest in environmental factors using a green marketing mix. The effect is high confidence in the operations of the specific urban hotel brand and a general state of increased loyalty to consuming their products and services [3]. It enables the hotel brand to integrate service to the primary and secondary consumers with response to their needs, especially the concerns about environmental sustainability. The strategic marketing 
approach is critical in optimizing the operations since performance depends on attracting and retaining customers to the brand by responding to their demands and needs [4]. The marketing mix increases the awareness of the customers on the commitment and dedication of the hotel brand to serve them with high-quality goods and services with minimal harm to the immediate natural environment.

Prior research [5] has explored the relationship between green customers and the green marketing mix in the hotel and hospitality industry. As the customers spend the various products and services, their central focus is the availability of environmentally friendly commodities and the effects on the surrounding after consumption. They are conscious of the marketing mix and are keen on the value gained by consuming from a specific brand that they have developed loyalty and preference. In this case, the designed and implemented marketing mix is the determining factor of the consumption decision and shows a meaningful relationship with the customer habits [6]. Some urban hotels respond to this relationship factor by occupying the primary and secondary customers with sensitive marketing strategies that target to show the company's commitment to ensure environmental sustainability and eliminate any negative impacts on its operating surroundings. Besides, there is a meaningful relationship between green customers and the public reputation maintained by a specific brand regarding environmental protection and conservation initiatives. A previous study [7] argued that the perception of these consumers is significantly influenced by the image and reputation maintained by a specific hotel entity in terms of sensitivity to protecting the environment. The purchasing decision is made following a critical consideration of other people's reviews and the public information available about these entities and the effects of their operations on sustainable environmental factors [8]. For instance, environmental awareness and sensitivity to its conservation may make a consumer reluctant to be associated with a hotel entity that has been subject to scandals like pollution and poor waste disposal, creating a negative reputation with members of the public.

Green customers show high interest in unique artwork in a hotel lobby and other interior design features because of the aesthetic value created and the general environmental appeal of the scenes. The customers are interested in the environmental aspects of style, lighting, color, and furnishing aspects of the lobby and other areas that contribute to the general physical environment in the hotel [9]. The environmental impacts integrated into the design and artwork of the lobby create an appealing and positive impact on the green customers' perception of the service quality and value addition from interacting with the brand's products and services [10]. Some of the most significant environmental elements that can be integrated into the artwork and interior design are lighting and color due to the identity with sustainability and originality appeal. The preference for specific artwork and interior design with identity to the environment is a psychological need that determines the loyalty and preferences of the green customers to a hotel brand. For instance, appealing artwork in a hotel lobby gives a sense of the actual physical environment. It may influence the decisions made by a green customer due to the identity created. Therefore, the overall psychological effect on the customers' behavior is influenced by the physical design aspect and the specific impression created [11,12]. A study on urban hotel service settings by Nogueira [13] shows that the positive response to the lobby artwork and interior design in a hotel is a performance determinant since it directly impacts the orientation of the green customers' preferences who form a significant part of the primary and secondary consumers.

\section{Research Gap}

A research gap exists for the increased environmental awareness and interest in artwork by the green customers and how these factors can be optimized to influence their consumption decision-making positively. There is limited information on strategic design and implementation of frameworks that integrate the artwork and interior design of the urban hotels into the response to the unique needs of green customers [14]. This research 
will bridge the gap by gathering comprehensive information on the existing factors and developing a practical framework exploring the effects of the physical hotel environment on green consumers. The nature and design of the physical environment play a critical role in attracting and retaining green customers and maintaining their loyalty, making it a critical research area [15]. One of the areas to be explored is the strategic design decisions focusing on considering the general interior design of the public spaces in a hotel environment and how they can be used as a factor to appeal to the psychological needs of the green customers, who are highly sensitive to the environment.

The present study adds value to the existing literature and addresses the areas of information insufficiency regarding the physical hotel environment. The design and appearance impacts of the lobby and other hotel environments are comprehensively explored in the research with the central aim of determining the actual impacts on impression, attitude, and preference by the green customers. The first impression created has a long-lasting impact on the general perception of a hotel entity and may affect their consumption decision in the long term [16]. Therefore, it is critical to incorporate quantitative statistical analysis tools such as correlational and comparative measures to analyze the details and provide results that can be implemented for better outcomes. The research should use the two mediating factors to determine the key aspects of green customers' decision-making that impact environmental awareness and loyalty to a hotel brand (See Figure 1).

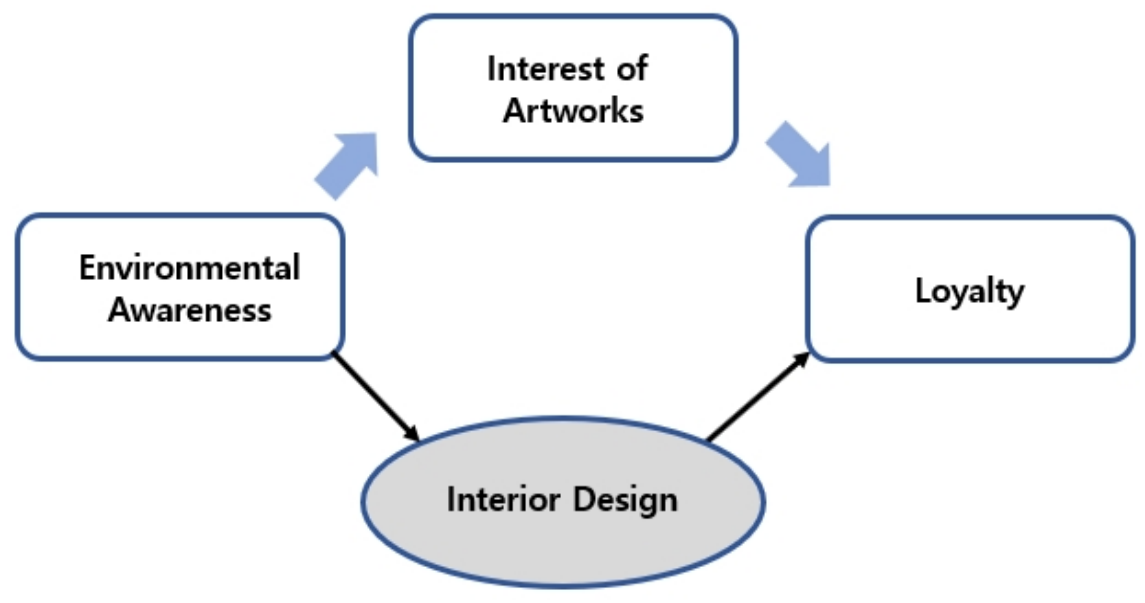

Figure 1. Research model of the present study.

To achieve this goal, this study used a 'Likert scale' $(1=$ Strongly Disagree $-5=$ Strongly Agree) with a total of 330 South Korean participants to check the mediating effect of hotel lobby interior design and artwork between green customers' preferences and hotel loyalty. All responses from participants were collected entirely through the professional survey agency in South Korea. The survey agency sent an email to the panelists, distributing men and women evenly from those in their 20 s to $60 \mathrm{~s}$, as we requested. The survey instrument designed for the current study included 15 main questions (Environmental awareness: 3 items, Interest in artwork: 5 items, Hotel interior design: 1 item, and Hotel loyalty: 6 items) to check the hypotheses.

\section{Literature Review}

\subsection{Importance of Environmental Marketing Strategy}

Environmental marketing strategies play a critical role in the ability of urban hotels to attract and retain green customers due to their high sensitivity and awareness of the environment. The existing research [17] argues that the success obtained from the marketing strategy depends on the ability to appeal to the unique psychological needs of the customers and their consciousness to maintain a general state of a sustainable environment. Environmental psychology acts as a premise for the marketing mix and designs the most appropriate communication method for the consumers [18]. Strategic communications are 
used as the main marketing tool. They are directed towards addressing the concerns and preferences of the green consumers who are continually conscious of their surroundings in terms of environmental sustainability and conservation. A strategic response to their needs by conducting initiatives indicates that the brand is responsible enough and keen on the environmental aspects and is ready to respond positively [19]. The marketing team should work to deliver quality information to the customers and inform them of the commitments and actions taken by the organization to address the underlying concerns with the actual physical environment.

According to the research conducted by Syaekhoni and his colleagues [20], the primary role of environmental marketing is to influence the green customers' perception by proving to them the extent to which the hotel is willing to go in response to environmental appeal and conservation. For instance, the product and service advertisement team can include details about the hotel's social responsibility initiatives and the environmental conservation duties by the company. The long-term effect of such initiatives is a positive perception developed by the consumers and a positive influence on their preferences due to the awareness of their surroundings and the value that should be added as they consume from the brand [21]. The marketing mix plays a critical role in showing how the hotel implements green practices and contributes significantly to sustainability [22]. Once the customers have built confidence in the hotel practices, they respond to the marketing efforts by developing preferences towards the various goods and services available. They also remain loyal and may influence other consumers who have similar interests to utilize the available goods and services [23]. Therefore, the marketing plan is carefully designed and implemented targeting to meet the unique needs of the green customers and respond to their psychological demands.

Further, a comprehensive study by Chung and his associates [24] reveals that an environmental marketing strategy enables the urban hotels to create a public reputation of response to the growing interest and concern for quality and environmentally appealing actions. The emerging pressure from the green consumers is addressed by portraying a public image and reputation of full commitment and investment in sustainability [25]. The investment programs are incorporated in the marketing communication plan, and the detailed information is passed to the consumers through advertisements and other initiatives. Prior research [26] also argues that the strategy shows how the hotel takes up the responsibility to implement more environmentally friendly practices and is conscious of its impacts on the surroundings as it serves the broad consumer base. In this case, the design planning and implementation stages are carefully initiated to meet the exclusive needs of the green consumers and directly respond to their concerns.

\subsection{Previous Studies on Relationships between Green Customers and Other Factors}

Bitner's various studies examine the relationship between green consumers and other factors like purchasing intentions, customer satisfaction, preferences, and brand loyalty. The research by Alamsyah and his colleagues [27] pays attention to the urban hotels that have been successful due to the in-depth understanding of how green customers develop their purchasing intentions and make decisions to consume products and services from a specific brand. This group of consumers has an outstanding feature in developing their purchasing intentions from environmentally appealing and protection activities [28]. The intentions are driven by the perception of the hotel's general response to sustainability and conservation of their immediate environment [29]. Purchasing intention is a significant factor in the performance of any entity in the hospitality industry since the intention is driven by the consciousness and awareness of the environment by the green consumers. Therefore, most organizations' management efforts and designed operational frameworks have an increasing interest in the relationship between these customers and their purchasing or consumption intentions [30]. The management efforts are directed towards ensuring that the intentions are aligned with the firms' positive practices and influence the state of performance excellence maintained in the dynamic industry. 
Moreover, a detailed study by Sureeyatanapas and his associates [31] gives the central argument that there is a meaningful relationship between the green customers and the satisfaction level from interacting with a brand's goods and services. Satisfaction comes from the attention to value and quality added from the output of the urban hotels in the process of serving their consumers. It is quantified by the value gained from interacting with the firm's activities within the natural environment and its unique ability to respond to the prevailing needs [32]. The current situation shows that the values and lifestyles of green consumers have been changing, and meeting their needs is one of the unique ways to increase their satisfaction level. In this case, satisfaction is a success factor with a meaningful relationship with green customers and their primary concern [33]. According to some studies on green customer behavior, satisfaction also depends on the importance given to the environment. It primarily influences purchasing from a given brand despite other substitutes and closely related firms in the same industrial category [27]. A change in consumer lifestyle towards environmental sustainability is directly proportional to their satisfaction with the goods and services they access from various hotels. The relationship makes it important for the urban hotels to put in efforts to add value and translate into a group of highly satisfied consumers who are willing and ready to interact with the brand output.

Additionally, studies on consumer behavior also show a meaningful relationship between green consumers and the factors of preferences. A gradual increase in the consumption from a hotel brand shows a positive change in preference of the primary and secondary consumers towards the available services [34]. Green consumers have a high inclination towards an entity primarily concerned with its impact on the environment and the extent to which it contributes or adds value to the surrounding environment. According to the argument by the authors of [35] on factors affecting preferences, a hotel that portrays high environmentally friendly standards is likely to have a wider consumer base since they prefer to purchase from the brand and not from the substitute firms. The phenomenon has prompted most hotel organizations to embrace sustainable development trends in response to preferences [36]. The development of green business practices by these organizations enables them to survive the dynamic forces in the market caused by the change in consumer preferences depending on their general perception of the response to sustainability and conservation. It is accurate to conclude that green consumers have a positive attitude and purchasing tastes oriented towards hotels that conduct green business and respond to the emerging trends regarding environmental conservation.

Green consumers also develop loyalty under various circumstances as they interact with different hotel brands in the hospitality industry. The commitment of these consumers to purchase and repurchase from their favorite brand is a measure of their loyalty and originates from the nature of operations by the specific entity. Sangroya and Nayak [37] claim that green consumers develop both transactional and emotional loyalty when their needs are met and the general conditions maintained in their selected brand meet their expectations. The effect is an increased volume of sales and a high market share because the buyers always come back to repurchase after the previous interactions with the goods and services [38]. Transactional loyalty is essential since it increases the consumer base and acts as a retention strategy. Green customers mainly develop this kind of loyalty when they are certain that the organization has full commitment to conduct eco-friendly activities and is continually aware of its impacts on the environment [39]. Emotional loyalty also plays a critical role in enhancing the consumer base since it is developed when the organization can address the unique needs of the green customers. They are likely to influence other secondary customers to the brand and continue purchasing and returning to buy regardless of the existence of other major firms in the competitive business environment.

\subsection{The Necessity of Customer's Interest in Artwork in Hotel Lobby Interior Design}

Green customers' interest in artwork and interior design forms a significant part of the design considerations to increase their brand loyalty. The artwork that makes the 
lobby layout appealing and attractive to the green customers is a priority in the initial design of the overall outlook due to the aesthetic value created and response to the unique consumer needs [40]. With the central aim to increase the loyalty and interests of green customers, the design stage is critical. It is systematically conducted to generate the expected results in terms of quality and value. The lobby can be made artistically green to generate the psychological appeal of environmental identity and influence the decisions made by the customers to return after the initial utilization of the products [41]. The target is to integrate the central design of the lobby with the ability to create value through appeal to environmental considerations and green operations [42]. A systematic and innovative artwork developed for the lobby can determine the value and resulting loyalty, making it a critical area of consideration at the management and technical levels [43]. The lobby design factors can be categorized into various groups, depending on the intended purpose or the nature of appeal that is to be achieved as the green customers access the hotel facility and decide on the long-term relationship to be maintained by the brand.

A previous study conducted by Ivanova and Basova [44] revealed that in addition to being conscious of the environment, green customers are also interested in appealing artwork and the interior design features that give a sense of satisfaction while interacting with a specific facility. The claim is reinforced by the idea that the lobby artwork and overall interior design give the initial impression of the inner state [45]. Design features represent the quality to be expected from the hotel and the brand image, making it an essential element to be considered for enhancing the ability to attract and gain the loyalty of green consumers [46]. Therefore, the features distinguishable from the artwork should follow a design criterion that aims to appeal to the customers and give the hotel brand an image of high value creation compared to the substitutes or closely related entities [47]. For example, the portrayal of green operations from the lobby artwork and complexity of the interior design would generate a psychological appeal to the consumers and give them an overview of how possible it is that they will be satisfied by the services and their exclusive needs met.

Bogicevic and Choi [48] also researched the connection between green consumer loyalty and the physical impression before consuming the actual goods or services. The central focus of the research was to determine how powerful the psychological appeal is and the direct influence on brand loyalty [49]. For instance, an artwork design in the lobby that portrays a green environment indicates possible environmentally friendly operations and full consciousness towards minimizing the negative effects to the surroundings. The impression then creates a positive image and reputation, the primary influencer of purchasing decisions and brand loyalty [50]. Therefore, the hotel lobby interior design choices are made to perform multiple roles of the actual functionality and influence on the consumers' psychological needs for environmental sustainability.

\subsection{Research Gap in the Literature}

There is a research gap between customer environmental awareness and their interest in artwork and interior design to gauge customer loyalty in an urban hotel setting. Few studies and research publications have explored how the awareness can be incorporated at the design stage for lobby artwork and the general interior design. There is a need for comprehensive information on the aspects that can be implemented to optimize the preference and loyalty of the green consumers towards an urban hotel brand [51]. The central area of focus is the first impression created from the initial interaction with the hotel environment through design features that appeal to the consumers' preferences. The close relationship between the customers' environmental awareness and the interior design and artwork can be used as the guiding framework to conduct a comprehensive study on how these factors can be utilized for a positive gain in an urban hotel setting for improving customer's revising rate.

Furthermore, the research gap features the styles used in hotel interior design and the integrated functions to transform the hotel into an entity that appeals to the consumers. 
There is insufficient information on how to balance the customers' environmental awareness and the resulting psychological needs for sustainability as they consume the various products and services. The initial experience before the actual stay is the determining factor of whether the guests will develop maximum interest towards the brand or will negatively impact the attitude and loyalty [52]. The research focuses on addressing the need or the prevailing problem from the root cause and devising the most appropriate framework that can be implemented for better results. Therefore, we suggest reasonably based on numerous previous studies that there are six hypotheses (See the below descriptions and Figure 2).

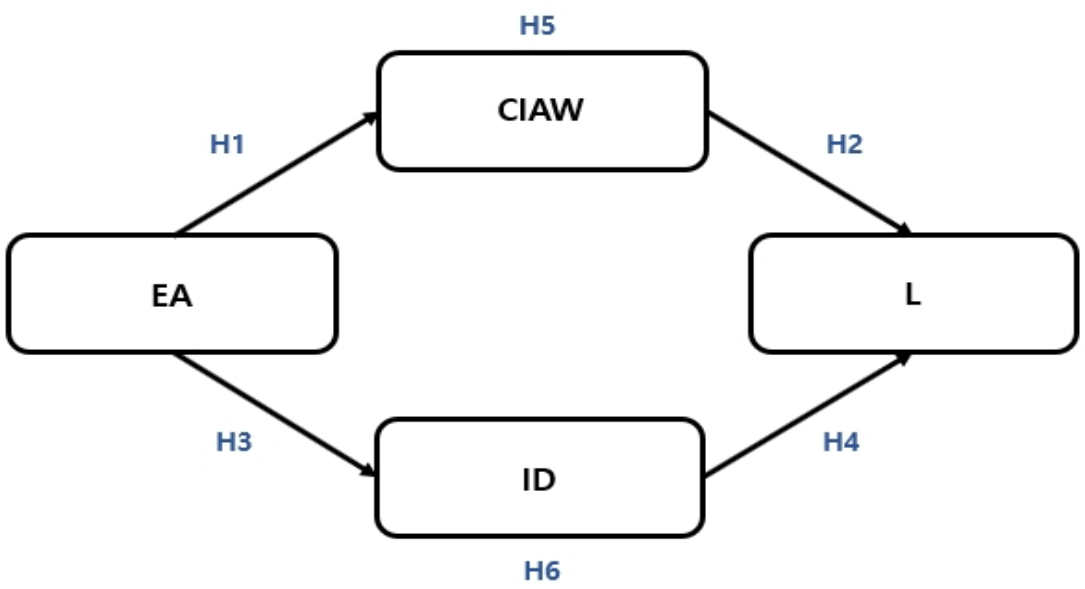

EA: Environmental Awareness, CIAW: Customer's Interest In Artwork, ID: Interior Design, L: Loyalty

Figure 2. Hypotheses of the study.

Hypothesis 1 (H1). The environmental awareness that green customers possess has a strong impact on their interest in artworks in hotels.

Hypothesis 2 (H2). Green customers' interest in artworks in hotels has a strong impact on hotel loyalty.

Hypothesis 3 (H3). The environmental awareness that green customers possess has a strong impact on the preference of the interior design in hotels.

Hypothesis $4 \mathbf{( H 4 ) . ~ T h e ~ p r e f e r e n c e ~ o f ~ t h e ~ i n t e r i o r ~ d e s i g n ~ i n ~ h o t e l s ~ h a s ~ a ~ s t r o n g ~ i m p a c t ~ o n ~ h o t e l ~ l o y a l t y . ~}$

Hypothesis 5 (H5). Customers'interest in artworks in hotels will mediate the relationship between the environmental awareness that green customers possess and their hotel loyalty.

Hypothesis 6 (H6). The preference of the interior design in hotels will mediate the relationship between the environmental awareness that green customers possess and their hotel loyalty.

\section{Research Design}

\subsection{Variables}

To add insight into the current literature, we explore and investigate a total of six hypotheses to identify paths between customers' level of environmental awareness and their level of loyalty in an urban hotel setting, using two mediating factors (Customer's interest in artwork and Interior design). For achieving this goal, the total survey question used 15 items. Table 1 indicates the summarized variable information, representing the number of questions and their sources, and Table 2 shows a detailed description of survey items. All survey questions were created by the current authors based on a number of previous studies. 
Table 1. Summarized variable information.

\begin{tabular}{ccc}
\hline Factors & Number of Questions & Resources \\
\hline $\begin{array}{c}\text { Environmental } \\
\text { Awareness }\end{array}$ & 3 & $\begin{array}{c}\text { (Kreidler, 2010; Yu et al., 2020; Zhang and } \\
\text { Wen, 2008). }\end{array}$ \\
$\begin{array}{c}\text { Customer's Interest in } \\
\text { Artwork }\end{array}$ & 5 & $\begin{array}{c}\text { (Lin, 2016; Lee et al., 2010; Norman, 2004; } \\
\text { Interior Design }\end{array}$ \\
Loyalty & 1 & $\begin{array}{c}\text { (Lin, 2016) } \\
\text { (Lin, 2016; Lee et al., 2010; Norman, 2004; }\end{array}$ \\
& 6 & McGuire, 1999; Nanu et al., 2020; Lin, 2019) \\
\hline
\end{tabular}

Table 2. Description of survey questions.

\begin{tabular}{|c|c|}
\hline Main Factors & Description of Survey Questions \\
\hline $\begin{array}{c}\text { Environmental } \\
\text { Awareness }\end{array}$ & $\begin{array}{l}\text { 1. I have been interested in the environmental field all the time. } \\
\text { 2. I prefer hotel lobby spaces with eco-friendly elements. } \\
\text { 3. I am willing to devote more effort and time to environmental } \\
\text { protection. }\end{array}$ \\
\hline $\begin{array}{l}\text { Customer's Interest } \\
\text { in Artwork }\end{array}$ & $\begin{array}{l}\text { 1. I am usually very interested in artworks. } \\
\text { 2. I usually go to exhibitions often. } \\
\text { 3. I have purchased artworks at an exhibition. } \\
\text { 4. When I see the artwork in the hotel lobby, I would like to hear the } \\
\text { curator's explanation. } \\
\text { 5. Do you think that the more different types of artwork give you the } \\
\text { more psychological satisfaction, interacting with them during } \\
\text { appreciating? }\end{array}$ \\
\hline Interior Design & I feel so good when I stay in a hotel with excellent interior design. \\
\hline Loyalty & $\begin{array}{l}\text { 1. I would like to reserve a hotel where artworks are displayed. } \\
\text { 2. Because I was impressed by the hotel where the artworks were } \\
\text { displayed, I have visited the hotel again. } \\
\text { 3. I am willing to pay more to stay in a hotel where artworks are } \\
\text { displayed. } \\
\text { 4. I prefer hotels with artworks over hotels which are not displayed } \\
\text { by artworks. } \\
\text { 5. I will speak positively to others about the art exhibition in the hotel } \\
\text { 6. I think my stay at the hotel will be extended due to art appreciation. }\end{array}$ \\
\hline
\end{tabular}

\subsection{Data Analysis and Collection}

In achieving the aim of the current research, we employed two initial arithmetical investigation tools, SPSS version 27 and AMOS 24.0, and tried to figure out the worth of the internal steadiness for influences. We were able to measure the reliability of the main factors' constructs. Moreover, we carried out both a confirmatory factor analysis (CFA) and exploratory factor analysis (EFA) to measure the validity concerning main factors through the suitability of the instruments of this research. We also tested the discriminant validity to verify the degree of possible overlying for the main concepts, gauging whether the square root of the AVEs has considerable additional information than correlation coefficients with other concepts, for the closing examination was tested to determine the scaling of the study suggestion by use of an operational equation modeling.

Concerning collecting the statistics, the study aimed to obtain more than 300 samples between 27 September 2021, to 29 September 2021 and the questionnaire was sent online. As seen in Table 3, although the total collected dataset revealed 380 participants, 50 samples should be discarded because participants responded illogically (ex: all survey questions were answered with the same number, or respondents failed to complete more than $20 \%$ of the questions) [53]. Prior studies have recommended that every researcher should check the obtained final dataset whether there are missing data first before conducting statistical 
investigating $[53,54]$ because the handling of missing data properly can increase the degree of data accuracy. The detailed procedure of the statistical collection is shown in Table 3 below.

Table 3. The information of the final obtained data.

\begin{tabular}{ccc}
\hline & Total & Percentage (\%) \\
\hline Collected Survey & 380 & $100 \%$ \\
Discarded Survey & 50 & $13.2 \%$ \\
Usable Survey & 330 & $86.8 \%$ \\
\hline
\end{tabular}

Demographic information regarding the respondents of the current study is shown in Table 4 . The overall features of the participants in the study who gave out feedback are depicted in the table as mentioned above. To obtain our sample evenly, we hired a professional research agency in South Korea so that they handled the data in a professional manner and provided us with accurate and high-quality data. The survey agency used a 'Stratified Random Sampling' type that conducts by classifying a population into groups with same features. This type's random mehod can guarantee that different divisions in a population can be assigned equally. As a result, we could collect the data which have perfect age and gender distribution as we requested to the agency. Regarding the characteristics of gender, 165 were male (50.0\%), and 165 were female (50.0\%). Concerning the age distribution of the participants, all five age groups had 66 respondents evenly (see more details in Table 4). The agency sent an invitation email first to their panelists, asking them to participate in the survey, and recipients could participate by filling out the survey if they accept the survey invitation. All in all, a total of 330 polling arrangements were used as a finalized usable sample in the previous investigative examination.

Table 4. Demographic information for usable sample.

\begin{tabular}{|c|c|c|}
\hline & Number of Participants & Percentage $(\%)$ \\
\hline \multicolumn{3}{|l|}{ Gender } \\
\hline Male & 66 & 50.0 \\
\hline Female & 66 & 50.0 \\
\hline \multicolumn{3}{|l|}{ Employment Status } \\
\hline Professional & 49 & 14.8 \\
\hline Administrative/Clerical & 100 & 30.3 \\
\hline Sales/Service & 30 & 9.1 \\
\hline Production/Technical & 29 & 8.8 \\
\hline Self-Employed & 25 & 7.6 \\
\hline Household & 55 & 16.7 \\
\hline Student & 24 & 7.3 \\
\hline Unemployed & 18 & 5.5 \\
\hline \multicolumn{3}{|l|}{ Age distribution } \\
\hline $20 \mathrm{~s}$ & 66 & 20.0 \\
\hline $30 \mathrm{~s}$ & 66 & 20.0 \\
\hline $40 \mathrm{~s}$ & 66 & 20.0 \\
\hline $50 \mathrm{~s}$ & 66 & 20.0 \\
\hline $60 \mathrm{~s}$ & 66 & 20.0 \\
\hline \multicolumn{3}{|l|}{ Monthly Income Level } \\
\hline Less than 2 million won *** & 26 & 7.9 \\
\hline $\begin{array}{c}2 \text { million won or More than } 2 \text { million won and } \\
\text { Less than } 4 \text { million won }\end{array}$ & 128 & 38.8 \\
\hline $\begin{array}{l}4 \text { million won or More than } 4 \text { million won and } \\
\text { Less than } 6 \text { million won }\end{array}$ & 83 & 25.2 \\
\hline $\begin{array}{c}6 \text { million won or More than } 6 \text { million won and } \\
\text { Less than } 8 \text { million won }\end{array}$ & 54 & 16.4 \\
\hline More than 8 million won & 39 & 11.8 \\
\hline
\end{tabular}




\section{Results}

\subsection{Descriptive Statistics}

As the first process of our statistical approach, we tested descriptive statistical analysis that mentions four basic statistics (Mean, Median, Difference between Max and Min, and Standard Deviation) (see Table 5 for more detail). All variables were measured by a fivepoint Likert scale ( 1 = Strongly Disagree-5 = Strongly Agree) As indicated in Table 5, regarding both the value of mean and standard deviation revealed 'Loyalty'.

Table 5. Descriptive statistics for final sample.

\begin{tabular}{ccccc}
\hline Factors & Mean & Median & Max-Min & STD \\
\hline Environmental Awareness & 2.68 & 2.44 & $4(5-1)$ & 0.893 \\
Customer's Interest of Artwork & 2.90 & 2.63 & $4(5-1)$ & 0.954 \\
Interior Design & 3.04 & 2.79 & $4(5-1)$ & 0.886 \\
Loyalty & 3.15 & 2.88 & $4(5-1)$ & 0.941 \\
\hline
\end{tabular}

\subsection{Reliability Analysis}

The data examination results concerning the collection of the primary dataset $(\mathrm{N}=330)$ are presented in this part. The information was analyzed using SPSS software version 27 and AMOS 24.0 to determine the relationship between our main constructs. All arithmetical conclusions were represented in tables with their interpretations provided in the text. In deciding the internal steadiness that shows a measure of gauge dependability, Cronbach's alpha value was applied using the generally accepted law. For instance, if the Cronbach value is 0.6 or more significant, a set of items is composed as a collection [53,55]. For the present research, the reliability coefficient value was 0.825 for 'Environmental Awareness', 0.776 for 'Interest in Artwork', and 0.804 for 'Loyalty'. The 'Interior Design' factor was not checked because it has only one variable so that we do not need to check an internal consistency between variables. As seen in Table 6, the result of internal consistency shows all factors' Cronbach alpha values are great than 0.6 and we could confirm all variables are reliable to measure our hypothesis.

Table 6. The statistical findings of reliability investigation.

\begin{tabular}{ccc}
\hline Sub-Factors & Question & The Value of Cronbach's $\alpha$ \\
\hline Environmental Awareness & $1-3$ & 0.825 \\
Interest in Artwork & $4-8$ & 0.776 \\
Loyalty & $10-15$ & 0.804 \\
\hline
\end{tabular}

\subsection{Exploratory Factor Analysis}

As a first step to measure the construct validity, we conducted the 'Exploratory Factor Analysis (EFA). EFA analysis reduces the data by discovering commonalities among variables. Previous studies have suggested that the Kaiser-Meyer-Olkin (KMO) value should be at least greater than 0.06 and the present research indicated for 0.772 that was greater than 0.06 . This meant the data was suitable to use in the factor analysis approach, with reliability value at 0.000 , less than 0.05 Therefore, it was considered acceptable.

In addition, using the Orthogonal Rotation with Varimax approach, Factor Extraction through Principal Component method was conducted. The received factors were considered from components which had variance of the variables (Eigenvalue) more than once $(>1)$. As we expected, there were three components (Environmental Awareness, Interest in Artworks and Loyalty) that followed the criteria and was made up of 14 variables. Because one of main factors (hotel interior design) contains only one variable, we do not need to add this factor when we conduct EFA analysis, assuming there is no multiplemeasurement variables to gauge commonality [56]. Therefore, the survey items of the present study were used to define the variables for dividing into three groups by using EFA. The variance 
value of all variables was $78.64 \%$ which can be the acceptable variance explained in factor analysis for a construct to be valid (See Tables 7 and 8).

Table 7. The result of suitability examination of unity matrix between variables.

\begin{tabular}{ccccc}
\hline \multirow{2}{*}{ Variable } & \multicolumn{2}{c}{ KMO } & \multicolumn{2}{c}{ Bartlett's Test } \\
\cline { 2 - 5 } 14 variables & $\begin{array}{c}\text { More than } 0.50(>0.9 \\
=\text { very good })\end{array}$ & 0.772 & Suitable Value & Received Value \\
\hline
\end{tabular}

Table 8. Components, eigenvalue, percentage of variance, and percentage of cumulative variance.

\begin{tabular}{|c|c|c|c|c|c|}
\hline Component & Main Factors & Number of Questions & Eigen Values & \% of Variance & Cumulative \% of Variance \\
\hline 1 & $\begin{array}{c}\text { Environmental } \\
\text { Awareness }\end{array}$ & 3 & 14.09 & 28.14 & 23.14 \\
\hline 2 & $\begin{array}{c}\text { Customer's } \\
\text { Interest in } \\
\text { Artwork }\end{array}$ & 5 & 11.66 & 23.49 & 51.63 \\
\hline 3 & Loyalty & 6 & 13.79 & 27.01 & 78.64 \\
\hline
\end{tabular}

\subsection{Confirmatory Factor Analysis}

Beyond the EFA analysis, the current research also conducted a confirmatory factor analysis (CFA) to gauge conversion validity and confirm whether three initial estimation factors sensibly clarified the inactive characteristics. CFA is a technique performed in the AMOS program that implements the structural equation model, and tests and confirms the relationship between the measured variable and the latent variable [57]. Altering acceptability attempts to examine the approximation of things dependably measure the essential idea and can be identified as the factor load between the idle and perceived variables. If the factors are not less than 0.5 , one can conclude that there is legitimacy. In Table 9, all values of the average variance extracted (AVE) are higher than 0.5 , which implies that all estimation factors can be confirmed as having altered legality since they uncovered more than the relating reference esteem (0.5) [58]. In addition to AVE values, we could check 'Construct Reliability'(CR) to double-check an internal consistency even if we already checked the 'Cronbach alpha' value (See Table 6). However, prior studies suggested that CR is a less biased estimate of reliability than 'Cronbach alpha' and the acceptable value of CR is 0.7 and above [59,60]. As seen in Table 9, all main factors' CR values were greater than 0.7 , thus, we could double-check a high degree of reliability for the constructs. We did not add the 'Interior Design' factor when conducting the CFA for the same reason as EFA [61].

\subsection{Discriminant Validity}

The current study's survey instrument also had another complicated means to gauge the quality of tools used. The research carried out both conversion validity and discriminant validity, explained by measures of academically differing concepts that should not correlate highly with one another [62]. Moreover, many past studies also insisted that the association analysis between the variables may come up with discriminant cogency validity through results less or negative association among variables [62]. After the convergent validity was measured, the discriminant validity was conducted utilizing Fornell and Lacker's [63] law. The discriminant validity examines the interconnection between constructs and recognized the probably covering figures. As shown in Table 10, the study tracked down that the square roots of AVEs are more noteworthy in all circumstances than the off-slanting components in their comparison line and section. Thus, they indicate that the critical discriminant validity has been confirmed. The summation of the estimation model commodified the acceptable prerequisites of the rightfulness discriminant validity. 
Table 9. The statistical findings of confirmatory factor analysis.

\begin{tabular}{|c|c|c|c|c|c|c|}
\hline Variables & $\begin{array}{l}\text { Unstandardized } \\
\text { Factor Loadings }\end{array}$ & $\begin{array}{c}\text { Standardized } \\
\text { Factor Loadings }\end{array}$ & S.E. & Critical Ratio & AVE & $\begin{array}{l}\text { Construct } \\
\text { Reliability }\end{array}$ \\
\hline EA1 & 1.00 & 0.89 & & & & \\
\hline EA2 & 0.81 & 0.72 & 0.5 & $18.12^{* * *}$ & 0.875 & 0.836 \\
\hline EA3 & 0.83 & 0.74 & 0.5 & $16.55^{* * *}$ & & \\
\hline CIAW1 & 1.00 & 0.90 & & & & \\
\hline CIAW2 & 0.85 & 0.74 & 0.5 & $18.34^{* * *}$ & & \\
\hline CIAW3 & 0.89 & 0.79 & 0.5 & $19.88^{* * *}$ & 0.849 & 0.798 \\
\hline CIAW4 & 0.75 & 0.68 & 0.5 & $20.65^{* * *}$ & & \\
\hline CIAW5 & 0.78 & 0.73 & 0.5 & $20.89^{* * *}$ & & \\
\hline LY1 & 1.00 & 0.93 & & & & \\
\hline LY2 & 0.88 & 0.80 & 0.6 & $22.16^{* * *}$ & & \\
\hline LY3 & 0.91 & 0.83 & 0.6 & $20.73^{* * *}$ & & \\
\hline LY4 & 0.86 & 0.78 & 0.6 & $22.59 * * *$ & 0.883 & 0.862 \\
\hline LY5 & 0.82 & 0.71 & 0.6 & $23.91^{* * *}$ & & \\
\hline LY6 & 1.01 & 0.94 & 0.6 & $23.64^{* * *}$ & & \\
\hline
\end{tabular}

Table 10. The results of discriminant validity.

\begin{tabular}{cccc}
\hline Construct & $\mathbf{1}$ & $\mathbf{2}$ & $\mathbf{3}$ \\
\hline 1. Environmental & 0.831 & & \\
Awareness & 0.655 & 0.923 & \\
2. Interest in Artwork & 0.611 & 0.703 & 0.714 \\
4. Loyalty & & & \\
\hline
\end{tabular}

\subsection{Structural Equation Modeling (SEM)}

To gauge the associations between our main factors, the present study conducted structural equation modeling (SEM), which is defined as a set of statistical approach used to analyze the associations between observed and latent variables. Numerous previous researchers have insisted that SEM can be more dominant tool to examine causal linkages among constructs than regression methods [64-66] because it can measure how strong variables have linear causal associations with each other unlike regression analyses, and even calculates the errors which implies residuals may be estimated and eliminated, indicating no measurement error on observed variables $[67,68]$. Moreover, the SEM also produces a more adequate inference structure for mediation investigation to gauge an indirect effect, testing complex and multiple mediating effects in a single anlayss [69].

For this reason, we selected the SEM for the statistical methodology of the present study to check the strong and weak causal effects of both (a) direct effects and (b) indirect effects between main factors. Before taking a look at an adequate statistical explanation of the indirect effects of this study, Figure 3 first presents the direct effects between the main factors of this study. Our SEM structure set in the equation for direct effects is as follows:

$$
\mathrm{Y}=\beta+\mathrm{C} 1 \mathrm{X} 1+\mathrm{C} 2 \mathrm{X} 2+\mathrm{C} 3 \mathrm{X} 3 \ldots+\varepsilon
$$

where $C$ is the slope coefficient that indicates the association between main factors. In the research model of the present study, $C$ should the direct effect of EA on LY. Y indicates the dependent factor (DF) and in this study, the DF can be all main factors except 'Environmental Awareness' (EA). X indicates the independent factor (IF) and can be all main factors except the 'Loyalty' factor (see Figure 3). The number of $X$ in Equation (1) depends on how many variables the independent factor has. For instance, because CIAW has five variables, the equation of direct effect for CIAW on the LY should be $Y=\beta+C 1 X 1+C 2 X 2+C 3 X+$ $\mathrm{C} 4 \mathrm{X} 4+\mathrm{C} 5 \mathrm{X} 5+\varepsilon$. In addition to DF and IF, the epsilon $(\varepsilon)$ presents an error associated with the indicators, and the beta $(\beta)$ points out the intercept coefficient in Equation (1). 


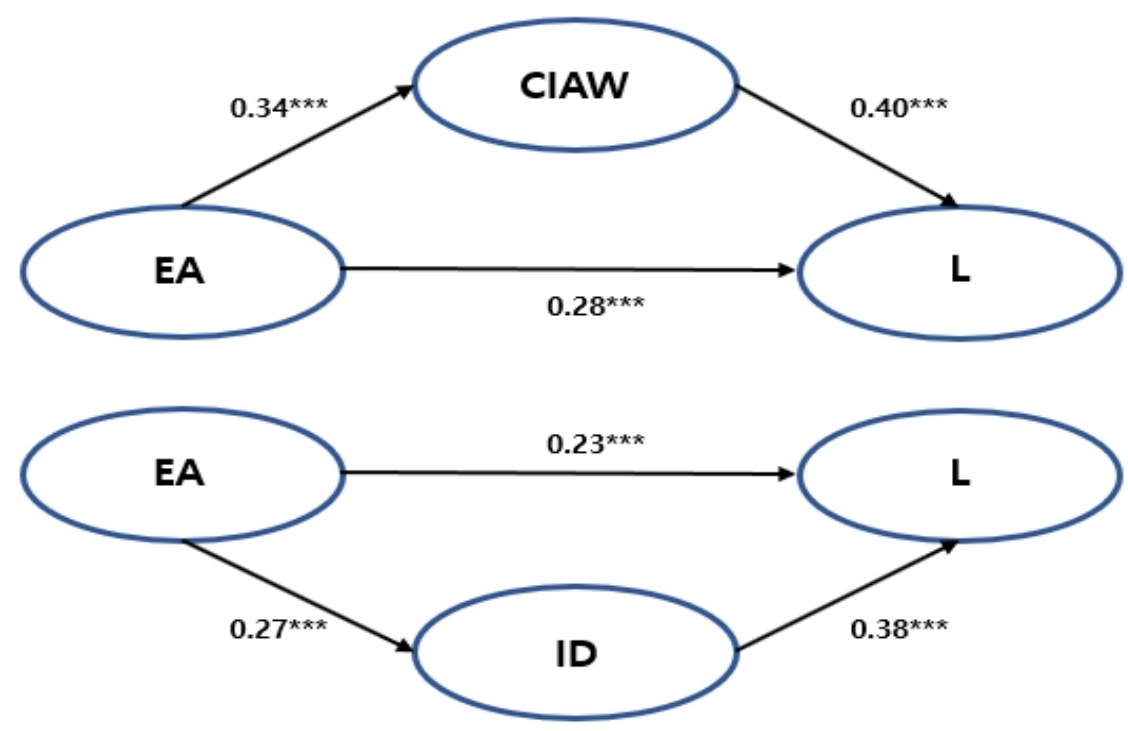

Figure 3. The result of the path analysis. ${ }^{* * *} p<0.001$.

As a next step to check how well our sample data fit with a normal distribution, we investigated our SEM model's suitableness. We used $\chi^{2}$, RMR, TLI, GFI, CFI, and RMSEA, indicating the research model's fitness. The model fit of SEM tests how well the conceptual model fits among our main factors (EA, CIAW, ID, and LY). In more detail, the absolute fit was measured through $\chi^{2}\left(\mathrm{Chi}^{2}\right)$, RMR (Root Mean Square Residual), GFI (Goodness of Fit Index), RMSEA (Root Mean Square Error of Approximation), and the incremental fit could be identified by the TLI (Tucker Lewis Index) and CFI (Comparative Fit Index).

To judge whether the $\chi^{2}\left(\mathrm{Chi}^{2}\right)$ of this study is a significant level statistically, we checked the difference between the value of our test statistic $\left(\chi^{2}=256.18\right)$ and the value of 'Degree of Freedom'(df) (95). Since 256.18 > 95, we could accept our $\chi^{2}\left(\mathrm{Chi}^{2}\right)$, rejecting the null hypothesis [70,71]. Regarding the value of CFI and TLI, prior studies have suggested being higher than 0.90 to indicate acceptable goodness of fit [72,73] and our results showed that both CRI and TLI values of this study are greater than 0.9 . The GFI value was also measured for our research model (SEM) and the result was within an acceptable range (between 0 and 1) [74], indicating 0.899. In terms of RMSEA and RMR value, the previous research confirmed that values lower than 0.06 were preferred (values lower than 0.08 were still acceptable) [75]. As seen the Table 11, both RMSEA and RMR values for the present study could be checked within the preferred range.

Table 11. The model results in $Y=\beta+C 1 X 1+C 2 X 2+C 3 X 3 \ldots+\varepsilon$.

\begin{tabular}{|c|c|c|c|c|}
\hline Path & $\begin{array}{l}\text { Unstandardized } \\
\text { Coefficients }\end{array}$ & $\begin{array}{c}\text { Standardized } \\
\text { Coefficients }(\beta)\end{array}$ & S.E. & $\mathrm{T}$ \\
\hline From EA to CIAW & 0.39 & 0.34 & 0.06 & $0.625^{* * *}$ \\
\hline From CIAW to LY & 0.45 & 0.40 & 0.06 & $0.644^{* * *}$ \\
\hline From EA to ID & 0.31 & 0.27 & 0.07 & $0.673^{* * *}$ \\
\hline From ID to LY & 0.42 & 0.38 & 0.06 & $0.697^{* * *}$ \\
\hline Index of Fitness & \multicolumn{2}{|c|}{ Suggested Range } & \multicolumn{2}{|c|}{ The Present Study's Range } \\
\hline RMR & \multicolumn{2}{|c|}{ Should be less than 0.08} & \multicolumn{2}{|c|}{$0.015($ Accepted $)$} \\
\hline GFI & \multicolumn{2}{|c|}{ Should be between 0 and 1} & \multicolumn{2}{|c|}{0.899 (Accepted) } \\
\hline TLI & \multicolumn{2}{|c|}{ Should be greater than 0.90} & \multicolumn{2}{|c|}{0.951 (Accepted) } \\
\hline CFI & \multicolumn{2}{|c|}{ Should be greater than 0.90} & \multicolumn{2}{|c|}{0.941 (Accepted) } \\
\hline RMSEA & \multicolumn{2}{|c|}{ Should be less than 0.08} & \multicolumn{2}{|c|}{0.049 (Accepted) } \\
\hline
\end{tabular}

$\chi^{2}=256.18(d f=95, \mathrm{p}<0.001) * * * p<0.001$. 
As a result of the final analysis of the path coefficient, the creation of EA had a significant positive $(+)(\beta=0.34, p<0.001)$ effect on CIAW $(\mathrm{H} 1)$ and hotel ID $(\mathrm{H} 3)(\beta=0.27$, $p<0.001)$. Additionally, a strong relationship was proven between hotel LY and the CIAW customers possess (H2) $(\beta=0.40, p<0.001)$, and between hotel LY and hotel ID (H4) $(\beta=0.38, p<0.001)$. Figure 3 presents the values of standardized coefficients $(\beta)$ between paths of main factors. Table 11 also presents the main results of the path analysis and all components of the 'Index of Fitness' and their interpretations for our structural equation model. As seen in Table 11, all components were found to be within an acceptable range. According to the statistical findings, fortunately, as indicated in Table 11, our first four hypotheses ( $\mathrm{H} 1, \mathrm{H} 2, \mathrm{H} 3$, and $\mathrm{H} 4)$ were found out in the expected directions, and therefore, we could accept them (see Table 11).

Lastly, to measure our fifth and sixth hypotheses, the mediating effect of 'Customer's interest in Artwork' (CIAW) and 'Interior Design' (ID) on 'Environmental Awareness' (EA) and 'Hotel Loyalty' (LY) was checked. Ramli and his colleagues [64] have insisted that an adequate mathematical equation for indirect effect should be the following:

$$
\mathrm{Y}=\beta+\mathrm{C} 1 \mathrm{X} 1+\mathrm{C} 2 \mathrm{X} 2+\mathrm{C} 3 \mathrm{X} 3 \ldots+\mathrm{BM}+\mathrm{e}
$$

In Equation (2), B can be expressed as a slope coefficient that implies the linkage between main factors. In the current research model, B points out the direct effect of CIAW on LY. M is the mediating factor with multiple variables. As already seen, the present study measured two mediating factors (CIAW and ID). In Equation (2), EA and LY can be X and $Y$ respectively in the current research model (See the Figure 3). The mathematical equation of $\mathrm{M}$ should the following:

$$
\mathrm{M}=\beta+\mathrm{A} 1 \mathrm{X} 1+\mathrm{A} 2 \mathrm{X} 2+\mathrm{A} 3 \mathrm{X} 3 \ldots+\mathrm{BM}+\mathrm{e}
$$

Using the AMOS program, the present study conducted the 'Bootstrap' method to check whether indirect effects in our research model are statistically significant. The 'Bootstrap' technique is a method of generating the distribution of parameters based on sample data without knowing the distribution of the population and then estimating the parameters [76]. It also produces a test that is not based on large-sample theory, meaning it can be applied to small samples with more confidence [24,77]. In this case, 5000 bootstrap samples were used, and 0 is not included in the $95 \%$ confidence interval of the indirect effect. Otherwise, the mediating effect can be considered as a significant value. As can be seen below in Tables 12 and 13, the indirect effect of CIAW between the EA and LY revealed (1) 0.14, and the indirect effect of ID between the EA and LY resulted in (2) 0.10 The mediating effect was strong because the $95 \%$ confidence interval was not contained 0 for the indirect effects [78] between 'Environmental Awareness' and 'Hotel Loyalty' (see Tables 12 and 13).

Table 12. The indirect effect of CIAW.

\begin{tabular}{cccc}
\hline Path & Indirect Effect & S.E & $\begin{array}{c}\text { 95\%CI } \\
\text { (Bias-Corrected Bootstrap) }\end{array}$ \\
\hline EA $\rightarrow$ CIAW $\rightarrow$ LY & 0.14 & 0.07 & $(0.09-0.19)$ \\
\hline Number of bootstrap samples: 5000. & &
\end{tabular}

Table 13. The indirect effect of ID.

\begin{tabular}{cccc}
\hline Path & Indirect Effect & S.E & $\begin{array}{c}\text { 95\%CI } \\
\text { (Bias-Corrected Bootstrap) }\end{array}$ \\
\hline EA $\rightarrow$ ID $\rightarrow$ LY & 0.10 & 0.06 & $(0.09-0.19)$ \\
\hline Number of bootstrap samples: 5000. & &
\end{tabular}


To double-check the results of the mediating effect of CIAW and ID, we investigated $\beta$ values (1) EA to CIAW: 0.34, CIAW to LY: 0.40, (2) EA to ID: 0.27, ID to LY: 0.38 (see Figure 3 and Table 11). As a result, we could double-check that there are indirect effects between EA and LY when both CIAW and ID perform their mediating roles $(0.34 \times 0.40=0.14)($ see Table 12), $(0.27 \times 0.38=0.10)($ see Table 13$)$.

Finally, the results of the indirect effect showed that our fifth and sixth hypotheses were also confirmed in our expected direction and we could accept them as well. As seen by statistical findings, the mediating effect of customers' interest in artwork was greater than the mediating effect of hotel interior design.

Additionally, we investigated the differences of two mediating factors depending on gender and income level. According to our investigation, female participants (CIAW: 0.17 and ID: 0.14) were revealed to have stronger mediating effect than male participants (CIAW: 0.15 and ID: 0.11) regarding two mediating factors ('Interest in Artwork' and 'Interior Design'). In the perspective of income level, the high-income group (CIAW: 0.18 and ID: $0.16)$ reacted more to the two mediating factors of environmental awareness and hotel loyalty than low-income level customers (CIAW: 0.11 and ID: 0.12). Table 14 presents the findings of the difference of the mediating effect depending on gender and income level.

Table 14. The indirect effect depending on gender and income level.

\begin{tabular}{|c|c|c|c|}
\hline Path & $\begin{array}{l}\text { Indirect Effect } \\
\text { (Female, } \mathrm{N}=165)\end{array}$ & S.E & $\begin{array}{c}95 \% \mathrm{CI} \\
\text { (Bias-Corrected Bootstrap) }\end{array}$ \\
\hline $\mathrm{EA} \rightarrow \mathrm{CIAW} \rightarrow \mathrm{LY}$ & 0.17 & 0.07 & $(0.09-0.19)$ \\
\hline Path & $\begin{array}{l}\text { Indirect Effect (Male, } \\
\qquad N=165 \text { ) }\end{array}$ & S.E & $\begin{array}{c}95 \% \mathrm{CI} \\
\text { (Bias-corrected bootstrap) }\end{array}$ \\
\hline $\mathrm{EA} \rightarrow \mathrm{CIAW} \rightarrow \mathrm{LY}$ & 0.15 & 0.07 & $(0.09-0.19)$ \\
\hline Path & $\begin{array}{c}\text { Indirect Effect } \\
\text { (Female, } \mathrm{N}=165)\end{array}$ & S.E & $\begin{array}{c}95 \% \mathrm{CI} \\
\text { (Bias-corrected bootstrap) }\end{array}$ \\
\hline $\mathrm{EA} \rightarrow \mathrm{ID} \rightarrow \mathrm{LY}$ & 0.14 & 0.06 & $(0.09-0.19)$ \\
\hline Path & $\begin{array}{l}\text { Indirect Effect (Male, } \\
\qquad N=165)\end{array}$ & S.E & $\begin{array}{c}95 \% \mathrm{CI} \\
\text { (Bias-corrected bootstrap) }\end{array}$ \\
\hline $\mathrm{EA} \rightarrow \mathrm{ID} \rightarrow \mathrm{LY}$ & 0.11 & 0.06 & $(0.09-0.19)$ \\
\hline Path & $\begin{array}{c}\text { Indirect Effect } \\
\text { (Income level above } \\
\text { the average, } \mathrm{N}=165 \text { ) }\end{array}$ & S.E & $\begin{array}{c}95 \% \mathrm{CI} \\
\text { (Bias-corrected bootstrap) }\end{array}$ \\
\hline $\mathrm{EA} \rightarrow \mathrm{CIAW} \rightarrow \mathrm{LY}$ & 0.18 & 0.07 & $(0.09-0.19)$ \\
\hline Path & $\begin{array}{c}\text { Indirect Effect } \\
\text { (Income level below } \\
\text { the average, } \mathrm{N}=165) \text { ) }\end{array}$ & S.E & $\begin{array}{c}95 \% \mathrm{CI} \\
\text { (Bias-corrected bootstrap) }\end{array}$ \\
\hline $\mathrm{EA} \rightarrow \mathrm{CIAW} \rightarrow \mathrm{LY}$ & 0.11 & 0.07 & $(0.09-0.19)$ \\
\hline Path & $\begin{array}{c}\text { Indirect Effect } \\
\text { (Income level above } \\
\text { the average, } \mathrm{N}=165 \text { ) }\end{array}$ & S.E & $\begin{array}{c}95 \% \mathrm{CI} \\
\text { (Bias-corrected bootstrap) }\end{array}$ \\
\hline $\mathrm{EA} \rightarrow \mathrm{ID} \rightarrow \mathrm{LY}$ & 0.16 & 0.06 & $(0.09-0.19)$ \\
\hline Path & $\begin{array}{c}\text { Indirect Effect } \\
\text { (Income level below } \\
\text { the average, } \mathrm{N}=165 \text { ) }\end{array}$ & S.E & $\begin{array}{c}95 \% \mathrm{CI} \\
\text { (Bias-corrected bootstrap) }\end{array}$ \\
\hline $\mathrm{EA} \rightarrow \mathrm{ID} \rightarrow \mathrm{LY}$ & 0.12 & 0.06 & $(0.09-0.19)$ \\
\hline
\end{tabular}

\section{Discussion}

Our findings indicate that it is statistically acceptable to relate the customers' environmental awareness with interest in artwork in the hotel lobby due to the first impression 
created. The artwork gives a general perception of the value and quality that the consumer is likely to gain by interacting with the available products and services. It is also valid to conclude that the customers' environmental awareness closely relates to their preference for interior design. The preference for the overall appearance in the interior environment become more appealing if it shows full consciousness to the environmental factors. It is also true that the interest in artwork and interior design preference directly impacts consumer brand loyalty.

The findings also show a relatively weak relationship between customers' environmental awareness and their loyalty due to the influence of the other mediating factors. The mediating factors create a balance between the major elements having a close relationship and influences the general decisions made by the consumers to purchase from a specific urban hotel. From the analysis, environmental awareness is a critical area of consideration for designing and implementing various hotel operation aspects. The goals and objectives are to gain consumer loyalty and positively influence their preferences towards the brand regardless of the availability of other hotels with similar services.

The research is applicable in an academic environment by enabling learners to map the various variables affecting the interior design of urban hotels and how they relate. It also enables learners to critically analyze the relationship between the various research models and how the mediating variables play a critical role in creating a balance between them and optimizing the effects [79]. The conclusion drawn from the discussions has the educational benefit of showing how the information can be applied for better decision-making. It is appropriate for future academic research and a detailed evaluation of how organizations can manipulate various variables for better results [80]. It can also generate suggestive measures that address the prevailing problems from the root cause and create a better scenario for operations in various organizations.

Besides, the research is applicable in academic policy design and the generation of measures that can help in the detailed evaluation of findings to generate a meaningful conclusion. In this case, the conclusions follow from the findings and give the existing relationship between various variables [81]. The results are then used for decision-making and the development of strategic frameworks that can be used to initiate change [82].

The theoretical perspective of the research is also applicable for analyzing the mediating variables between the environmental awareness of the customers and their loyalty to a hotel brand. For instance, artwork in the hotel lobby is a variable with a mediating effect between the two entities. The research is applicable for analyzing how the lobby artwork can be optimized and designed to balance the two extremes and ensure that environmental awareness translates into positive effects in terms of brand loyalty [83]. Additionally, the preference for interior design can be used as another research variable that significantly mediates the relationship between the two factors (EA and LY in this study) [84]. The two variables are then used as academic decision-making tools to map the relationships between the basic factors and give recommendations for maximum efficiency and effectiveness.

Besides, the discussion and findings are relevant and significant for subsequent academic research on consumer behavior in the hospitality industry and interior design. They can be applicable for enhancing the available information on the critical operational aspects by focusing on the research gaps and devising techniques to bridge the gap by generating comprehensive information on the areas of study focus. The conclusions drawn also have academic relevance and give an overview of how the information can be implemented in the management framework design for strategic decision-making. They are important for assessing and explaining how the generated facts and relationships between variables apply in a practical business setting and can be used to generate a change framework [85]. Therefore, this study can positively impact academic research and the details used to reinforce the possible impacts of future analysis and data evaluation.

The study has practical implications for the practitioners in urban hotels for strategic decision-making and policy development targeting optimal operations. For instance, the marketing concept discussed is useful when dealing with green customers who are aware 
of their environment and are sensitive to the nature of products and services generated by a given hotel brand. The information is also relevant for the segmenting process. It enables the urban hotel practitioners to identify their primary and secondary customers, evaluate their needs, and design strategies to respond to the underlying demands [68]. The marketing information is applicable for strategic decision-making for better performance by ensuring that the relationship between the major variables is incorporated in the planning process and implemented in the change framework [86]. Therefore, the study is relevant and can be utilized in a practical hotel business environment where consumer needs and preferences are dynamic.

The practitioners in urban hotels can also utilize the research information for administrative functions to plan, design, and implement initiatives to optimize general performance. The description and detailed analysis of the green consumer behaviors and their environmental consciousness is integrated with the other practical frameworks to generate valuable results [87]. Combining these frameworks adds value and increases the outcome quality of the operations in urban hotels that mainly have customer-oriented services [88]. The long-term goal is to serve the customers with maximum efficiency and effectiveness, making the study details relevant and applicable in the decision-making processes at the administration level.

Other statistical results can be used to analyze how female customers are more inclined to mediate environmental awareness and loyalty. The factors can apply in a practical situation where the relevant criteria are applied in marketing segmentation and used for decision-making. The marketing mix is used to attract and retain the customers' loyalty and segment the given categories according to their preferences [89]. The preference for the interior design of the hotel and interest in artwork is more dominant with the female customers than male customers (see Table 14, indirect effect of female participants for both interest in artworks and interior design: 0.17 and 0.14 , indirect effect of male: 0.15 and 0.11 ). It plays a mediating role in their consumption decision and loyalty to a specific brand [90]. The findings become critical in this case because they show how the awareness of the environment and customer loyalty are also influenced by other aspects like the lobby artwork and interior design.

The comparison between impacts of the mediating factors between male and female consumers is useful. It can be integrated into the marketing mix to address the unique needs of each consumer segment. The market segmentation and orientation idea are well explored using the findings, with special attention given to the underlying needs and demands as the customers interact with the products and services [91]. Since the consumers in the hospitality industry have high bargaining power and their needs and preferences dynamic, the research information is relevant for performance optimization, especially when an environmental marketing strategy is successfully implemented [7]. The information is further relevant for the statistical determination of consumer behaviors in different environmental settings and how they can be optimized by exploring the related variables.

The research details also apply in addressing the growing concern for sustainability due to environmental awareness by the green consumers. People with high annual incomes have diverging perspectives. They are more mediated by the factors like interior design features and lobby artwork, meaning that a response to their needs can be achieved from an effective decision-making process (see Table 14, indirect effect of participants belonging to the high-income level for both interest in artworks and interior design: 0.18 and 0.16, indirect effect of participants belonging to the low-income level: 0.11 and 0.12) [92]. From the demographic trends, it is possible to create a meaningful relationship between the mediating variables and map the effects on this group of consumers who have unique preferences for the available products and services from their chosen brand [93]. When the needs are adequately addressed, high-income earners are likely to be more loyal to the hotel brand than the relatively low-income earners within the same environment.

The environmental awareness and hotel loyalty factors impact the marketing strategy and segmentation process used for the urban hotels that deal with green customers with unique and exclusive needs. The major segmentation sections are influenced by 
the information gained and the conclusions and inferences generated [94]. A marketing approach using the relevant information gives positive results. It can be applied in the hotel organizations with a central goal to ensure that their services are customer-oriented and applicable in meeting all the needs and preferences of the different consumer groups [95]. The groups comprise demographic factors and are differentiated by how environmental awareness affects their purchasing decision and brand loyalty.

\section{Limitations and Future Suggestions}

Future researchers and practitioners should remember the limitations given by the present study. Although the sample of participants for this study was an appropriate size for empirical study and the response rate was acceptable (see more details in Tables 2 and 3), the findings of the present study might have some limitations. First, the present study is limited by various factors that reduce the overall impact and influence it has on the topic being examined. For example, the research hypotheses were relatively broad, reducing the capability to narrow down to the areas that need maximum attention [1]. The broad nature also made the study quite general, with the findings limited to exploring the details about the relationships between the variables and the influence of the mediating factors. The limitation also led to a minimal exploration of key details and additional information on factors affecting consumer purchasing behavior and consumption decisions in urban hotels.

Second, another area of limitations is the relatively complex discussion scope and requires adequate knowledge and experience to explore effectively. For instance, the role of the mediating factors should be explored from a maximum experience standpoint and be evaluated critically to generate meaningful results [25]. The discussion scope and depth require technical capability and competence in analyzing customer behavior, especially for the green consumers [23]. The limited knowledge availability posed a challenge, especially for areas where detailed and critical analyses are required.

Lastly, there is insufficient prior research on the relationship between the variables and how they can be coordinated to generate better results. The research gaps from the existing literature also present a challenge to the analysis process and may affect the quality of the inferences generated [36]. The reduced quality is then reflected in the decision-making stage involving the behavioral analysis of the customers and how they can be oriented towards optimal conditions. Minimizing the research effects is a practical means of solving the customer behavior problems from the root cause and creating a better scenario [8]. In this case, the limitations act as a learning point for future research and can make better decisions that will positively impact performance and sustainability.

Future studies can be more impactful by narrowing the objectives and the hypothesis to specific areas of concern. The factors to be explored under objectives and hypotheses can then be examined in detail. The findings give a comprehensive representation of the area of interest while conducting the research [19]. This research approach is an effective strategy that can be implemented for subsequent and future studies involving a market phenomenon that directly affect performance and other factors like loyalty and preferences [39]. The critical analysis and evaluation of the variables also make the study relevant to the management team members who can use the facts to make suitable and impactful choices. Another important area of consideration in the future study is systematically presenting the details that can influence the decisions made and giving an overview of how consumer behaviors regarding interior design can be optimized to realize better results.

Another suggestion for approaches to future studies is to ensure the relationships between the given variable and other related variables to increase the comprehensiveness of the findings. The marketing approach should also integrate green marketing and other behavior determinants into the operational framework and present the details in the overall service method [19]. It should also include challenges associated with a framework and how learning points can be eliminated or used for better outcomes in future activities [18]. Addressing the challenges is appropriate since it forms part of a practical change framework 
for the hotel organization and can influence performance excellence in the dynamic business environment with consumers' continually changing preferences.

Author Contributions: Conceptualization, J.K.; investigation, J.K., E.K.; methodology, E.K.; project administration, J.K., E.K.; resources, J.K.; software, E.K.; writing—original draft, J.K., E.K.; writing—review and editing, J.K., E.K. All authors have read and agreed to the published version of the manuscript.

Funding: This research received no external funding.

Institutional Review Board Statement: Not applicable.

Informed Consent Statement: Not applicable.

Data Availability Statement: No data sharing is applicable to the current article.

Conflicts of Interest: The authors declare no conflict of interest.

\section{References}

1. AL-Ghaswyneh, O. Environmental marketing strategy in classified hotels. Manag. Sci. Lett. 2020, 10, 2751-2758. [CrossRef]

2. Chou, S.F.; Horng, J.S.; Liu, C.H.S.; Lin, J.Y. Identifying the critical factors of customer behavior: An integration perspective of marketing strategy and components of attitudes. J. Retail. Consum. Serv. 2020, 55, 102113. [CrossRef]

3. D'Souza, C.; Marjoribanks, T.; Young, S.; Sullivan Mort, G.; Nanere, M.; John, J.J. Environmental management systems: An alternative marketing strategy for sustainability. J. Strateg. Mark. 2019, 27, 417-434. [CrossRef]

4. Woo, E.J. Environmental Marketing Policy to Enhance Customers' Environmental Awareness. J. Distrib. Sci. 2020, 18, $23-30$.

5. Annamalai, S.; Kumar, K.R.; Jothikumar, R.; Hung, Y.T. Environmental sustainability of green marketing strategy: Empirical evidence from e-tail consumer's in Tamil Nadu. Int. J. Environ. Waste Manag. 2018, 22, 215-227. [CrossRef]

6. Ferreira, G.G.T.; Tavares, F.; Fialho, G.G. Green Consumption, Environmental Marketing and Green Advertising: A Look at the Privatization of Nature from the Perspective of Liquid Modernity. South Asian J. Soc. Stud. Econ. 2018, 2, 1-11. [CrossRef]

7. Dangelico, R.M.; Vocalelli, D. “Green Marketing": An analysis of definitions, strategy steps, and tools through a systematic review of the literature. J. Clean. Prod. 2017, 165, 1263-1279. [CrossRef]

8. Sugandini, D.; Irhas Effendi, M.; Sasmito Aribowo, A.; Sri Utami, Y. Marketing strategy on community based tourism in Special Region of Yogyakarta. J. Environ. Manag. Tour. 2018, 9, 733-743. [CrossRef]

9. Ghiyasabadi, M.; Ghafari, P. Eco-Friendly Marketing Strategy with the Role of Porter's Competitive Advantage. Commer. Surv. 2018, 16, 53-62.

10. Jain, A.; Darbari, J.D.; Kaul, A.; Jha, P.C. Selection of a green marketing strategy using MCDM under fuzzy environment. In Soft Computing for Problem Solving; Springer: Singapore, 2020; pp. 499-512.

11. Gelderman, C.J.; Schijns, J.; Lambrechts, W.; Vijgen, S. Green marketing as an environmental practice: The impact on green satisfaction and green loyalty in a business-to-business context. Bus. Strategy Environ. 2021, 30, 2061-2076. [CrossRef]

12. Sharif-Askari, H.; Abu-Hijleh, B. Review of museums' indoor environment conditions studies and guidelines and their impact on the museums' artifacts and energy consumption. Build. Environ. 2018, 143, 186-195. [CrossRef]

13. Nogueira, S. The importance of a green marketing strategy in brand communication-M. Coutinho multi-brand car dealer case in Northern Portugal. J. Econ. Bus. Organ. Res. 2020, 351-373.

14. Sadchenko, O.V.; Robul, I.V. Economic and environmental marketing space of the economics of experience. Econ. Innov. 2020, 22, 129-139. [CrossRef]

15. Morgan, N.A.; Whitler, K.A.; Feng, H.; Chari, S. Research in marketing strategy. J. Acad. Mark. Sci. 2019, 47, 4-29. [CrossRef]

16. Samiee, S.; Chirapanda, S. International marketing strategy in emerging-market exporting firms. J. Int. Mark. 2019, 27, $20-37$. [CrossRef]

17. Widyastuti, S.; Said, M.; Siswono, S.; Firmansyah, D.A. Customer trust through green corporate image, green marketing strategy, and social responsibility: A case study. Eur. Res. Stud. J. 2019, 22, 83-99. [CrossRef]

18. Alamsyah, D.P.; Suhartini, T.; Rahayu, Y.; Setyawati, I.; Hariyanto, O.I. Green advertising, green brand image and green awareness for environmental products. In IOP Conference Series: Materials Science and Engineering; IOP Publishing: Tokyo, Japan, 2018; Volume 434, p. 012160.

19. Vafaei, S.A.; Azmoon, I.; Fekete-Farkas, M. The impact of perceived sustainable marketing policies on green customer satisfaction. Pol. J. Manag. Stud. 2019, 19, 475-491. [CrossRef]

20. Syaekhoni, M.A.; Alfian, G.; Kwon, Y.S. Customer purchasing behavior analysis as alternatives for supporting in-store green marketing decision-making. Sustainability 2017, 9, 2008. [CrossRef]

21. Jabeen, S.S.; Kavitha, M. A Study on Customer Preferences on Green Marketing. Indian J. Public Health Res. Dev. 2019, 10, 211. [CrossRef]

22. Setiadi, R.; Batu, K.L.; Soesanto, H. Does an environmental marketing strategy influence marketing and financial performance? A study of Indonesian exporting firms. Mark.-Tržište 2017, 29, 177-192. [CrossRef] 
23. Saputra, M.H.; Kristyassari, B.; Farida, N.; Ardyan, E. An Investigation of Green Product Innovation on Consumer Repurchase Intention: The Mediating Role of Green Customer Value. J. Environ. Manag. Tour. 2020, 11, 622-633. [CrossRef]

24. Chung, K.C. Green marketing orientation: Achieving sustainable development in green hotel management. J. Hosp. Mark. Manag. 2020, 29, 722-738. [CrossRef]

25. Sugandini, D.; Muafi, M.; Susilowati, C.; Siswanti, Y.; Syafri, W. Green supply management and green marketing strategy on green purchase intention: SMEs cases. J. Ind. Eng. Manag. 2020, 13, 79-92. [CrossRef]

26. Trang, H.L.T.; Lee, J.S.; Han, H. How do green attributes elicit pro-environmental behaviors in guests? The case of green hotels in Vietnam. J. Travel Tour. Mark. 2019, 36, 14-28. [CrossRef]

27. Alamsyah, D.; Aryanto, R.; Utama, I.; Marita, L.; Othman, N. The antecedent model of green awareness customer. Manag. Sci. Lett. 2020, 10, 2431-2436. [CrossRef]

28. González-Rodríguez, M.R.; Díaz-Fernández, M.C.; Font, X. Factors influencing willingness of customers of environmentally friendly hotels to pay a price premium. Int. J. Contemp. Hosp. Manag. 2020, 32, 60-80. [CrossRef]

29. Moravcikova, D.; Krizanova, A.; Kliestikova, J.; Rypakova, M. Green Marketing as the Source of the Competitive Advantage of the Business. Sustainability 2020, 9, 2218. [CrossRef]

30. Sarmiento, C.V.; El Hanandeh, A. Customers' perceptions and expectations of environmentally sustainable restaurant and the development of green index: The case of the Gold Coast, Australia. Sustain. Prod. Consum. 2018, 15, 16-24. [CrossRef]

31. Sureeyatanapas, P.; Poophiukhok, P.; Pathumnakul, S. Green initiatives for logistics service providers: An investigation of antecedent factors and the contributions to corporate goals. J. Clean. Prod. 2018, 191, 1-14. [CrossRef]

32. Wang, Y.; Li, Y.; Zhang, J.; Su, X. How impacting factors affect Chinese green purchasing behavior based on Fuzzy Cognitive Maps. J. Clean. Prod. 2019, 240, 118199. [CrossRef]

33. Lisi, W.; Zhu, R.; Yuan, C. Embracing green innovation via green supply chain learning: The moderating role of green technology turbulence. Sustain. Dev. 2020, 28, 155-168. [CrossRef]

34. Nam, C.; Dong, H.; Lee, Y.A. Factors influencing consumers' purchase intention of green sportswear. Fash Text $2017,4,2$. [CrossRef]

35. Melander, L. Achieving sustainable development by collaborating in green product innovation. Bus. Strategy Environ. 2017, 26, 1095-1109. [CrossRef]

36. Zameer, H.; Wang, Y.; Yasmeen, H. Reinforcing green competitive advantage through green production, creativity and green brand image: Implications for cleaner production in China. J. Clean. Prod. 2020, 247, 119119. [CrossRef]

37. Sangroya, D.; Nayak, J.K. Factors influencing buying behaviour of green energy consumer. J. Clean. Prod. 2017, 151, 393-405. [CrossRef]

38. Tariq, A.; Badir, Y.; Chonglerttham, S. Green innovation and performance: Moderation analyses from Thailand. Eur. J. Innov. Manag. 2019, 22, 446-467. [CrossRef]

39. Song, W.; Yu, H. Green innovation strategy and green innovation: The roles of green creativity and green organizational identity. Corp. Soc. Responsib. Environ. Manag. 2018, 25, 135-150. [CrossRef]

40. Bogicevic, V.; Bujisic, M.; Cobanoglu, C.; Feinstein, A.H. Gender and age preferences of hotel room design. Int. J. Contemp. Hosp. Manag. 2018, 30, 874-899. [CrossRef]

41. $\mathrm{Wu}, \mathrm{S} . \mathrm{H}$;; Gao, Y. Understanding emotional customer experience and co-creation behaviours in luxury hotels. Int. J. Contemp. Hosp. Manag. 2019, 31, 4247-4275. [CrossRef]

42. Sadhale, M.; Sathe, S. A Study of impact of Room interior design and decoration on guest experience in star hotels. MultiDisciplinary J. 2021, 1, 1-23.

43. Floricic, T. Art inspired hotels-competitiveness context and market positioning. In Economic and Social Development: Book of Proceedings 10-25; Varazdin Development and Entrepreneurship Agency: Varazdin, Croatia, 2020.

44. Ivanova, M.G.; Basova, P. Customer Perceptions of the Design of Lifestyle Hotels. In Proceedings of the International Conference "Tourism beyond Expectations", Sofia, Bulgaria, 25-26 September 2020; pp. 215-224.

45. Kirillova, K.; Fu, X.; Kucukusta, D. Workplace design and well-being: Aesthetic perceptions of hotel employees. Serv. Ind. J. 2020, 40, 27-49. [CrossRef]

46. Lin, Q. Design Characteristics of Culturally-Themed Luxury Hotel Lobbies in Las Vegas: Perceptual, Sensorial, and Emotional Impacts of Fantasy Environments. Ph.D. Thesis, Iowa State University, Ames, IA, USA, 2020.

47. Flock, B. Enhancing the Business Traveler Experience though Hotel Design. Ph.D. Thesis, The Florida State University, Tallahassee, FL, USA, 2018.

48. Bogicevic, V.; Choi, H. Designing Service Environments. In Operations Management in the Hospitality Industry; Emerald Publishing Limited: Bradford, UK, 2021.

49. Baek, J.; Ok, C.M. The power of design: How does design affect consumers' online hotel booking? Int. J. Hosp. Manag. 2017, 65, 1-10. [CrossRef]

50. Ozkan, A.; Yildirim, K.; Tuna, D. Influence of Design Styles on User Preferences in Hotel Guestrooms. Online J. Art Des. 2017, 5, 53-71.

51. Jiang, W.; Chai, H.; Shao, J.; Feng, T. Green entrepreneurial orientation for enhancing firm performance: A dynamic capability perspective. J. Clean. Prod. 2018, 198, 1311-1323. [CrossRef] 
52. Lundgren, T.; Zhou, W. Firm performance and the role of environmental management. J. Environ. Manag. 2017, $203,330-341$. [CrossRef]

53. Woo, E.J.; Kang, E. Employee Environmental Capability and Its Relationship with Corporate Culture. Sustainability 2021, 13, 8684. [CrossRef]

54. Scholz, M.; Kaplan, F.; Guy, C.L.; Kopka, J.; Selbig, J. Non-linear PCA: A missing data approach. Bioinformatics 2005, 21, $3887-3895$. [CrossRef]

55. Heo, M.; Kim, N.; Faith, M.S. Statistical power as a function of Cronbach alpha of instrument questionnaire items. BMC Med. Res. Methodol. 2005, 15, 86. [CrossRef]

56. Beavers, A.S.; Lounsbury, J.W.; Richards, J.K.; Huck, S.W.; Skolits, G.J.; Esquivel, S.L. Practical considerations for using exploratory factor analysis in educational research. Pract. Assess. Res. Eval. 2013, 18, 6.

57. Kyriazos, T.A. Applied psychometrics: Sample size and sample power considerations in factor analysis (EFA, CFA) and SEM in general. Psychology 2018, 9, 2207. [CrossRef]

58. Marsh, H.W.; Muthén, B.; Asparouhov, T.; Lüdtke, O.; Robitzsch, A.; Morin, A.J.; Trautwein, U. Exploratory structural equation modeling, integrating CFA and EFA: Application to students' evaluations of university teaching. Struct. Equ. Model. A Multidiscip. J. 2009, 16, 439-476. [CrossRef]

59. De Falco, S.E.; Scandurra, G.; Thomas, A. How stakeholders affect the pursuit of the Environmental, Social, and Governance Evidence from innovative small and medium enterprises. Corp. Soc. Responsib. Environ. Manag. 2021, 28, 1528-1539. [CrossRef]

60. Djakasaputra, A.; Wijaya, O.; Utama, A.; Yohana, C.; Romadhoni, B.; Fahlevi, M. Empirical study of Indonesian SMEs sales performance in digital era: The role of quality service and digital marketing. Int. J. Data Netw. Sci. 2021, 5, 303-310. [CrossRef]

61. Steinmetz, H.; Schmidt, P.; Tina-Booh, A.; Wieczorek, S.; Schwartz, S.H. Testing measurement invariance using multigroup CFA: Differences between educational groups in human values measurement. Qual. Quant. Int. J. Methodol. 2009, 43, 599-616. [CrossRef]

62. Manfra, M.M.; Bolick, C.M. The Wiley Handbook of Social Studies Research; John Wiley \& Sons: Hoboken, NJ, USA, 2017.

63. Fornell, C.; Larcker, D.F. Evaluating structural equation models with unobservable variables and measurement error. J. Mark. Res. 1981, 18, 39-50. [CrossRef]

64. Ramli, N.A.; Latan, H.; Nartea, G.V. Why should PLS-SEM be used rather than regression? Evidence from the capital structure perspective. In Partial Least Squares Structural Equation Modeling; Springer: Cham, Switzerland, 2018; pp. 171-209.

65. Rijnhart, J.J.; Twisk, J.W.; Eekhout, I.; Heymans, M.W. Comparison of logistic-regression based methods for simple mediation analysis with a dichotomous outcome variable. BMC Med. Res. Methodol. 2019, 19, 19. [CrossRef] [PubMed]

66. Mohamad, M.; Afthanorhan, A.; Awang, Z.; Mohammad, M. Comparison between CB-SEM and PLS-SEM: Testing and confirming the maqasid syariah quality of life measurement model. J. Soc. Sci. Res. 2019, 5, 608-614. [CrossRef]

67. Kock, N. A note on how to conduct a factor-based PLS-SEM analysis. Int. J. e-Collab. (IJeC) 2015, 11, 10. [CrossRef]

68. Malang-Indonesia, J.V. A study on the correlation measurement errors in structural equation modeling (SEM) analysis. Appl. Math. Sci. 2014, 8, 7301-7309.

69. Gunzler, D.; Chen, T.; Wu, P.; Zhang, H. Introduction to mediation analysis with structural equation modeling. Shanghai Arch Psychiatry 2013, 25, 390.

70. Sharpe, D. Chi-square test is statistically significant: Now what? Pract. Assess. Res. Eval. 2015, 20, 8.

71. Jain, D.; Mandot, N. Impact of demographic factors on investment decision of investors in Rajasthan. Res. World $2012,3,81$.

72. Liu, G.; Li, K.; Zhao, D.; Mao, C. Business model innovation and its drivers in the Chinese construction industry during the shift to modular prefabrication. J. Manag. Eng. 2017, 33, 04016051. [CrossRef]

73. Epstein, J.; Osborne, R.H.; Elsworth, G.R.; Beaton, D.E.; Guillemin, F. Cross-cultural adaptation of the Health Education Impact Questionnaire: Experimental study showed expert committee, not back-translation, added value. J. Clin. Epidemiol. 2015, 68, 360-369. [CrossRef]

74. Mariman, A.; Vogelaers, D.; Hanoulle, I.; Delesie, L.; Tobback, E.; Pevernagie, D. Validation of the three-factor model of the PSQI in a large sample of chronic fatigue syndrome (CFS) patients. J. Psychosom. Res. 2012, 72, 111-113. [CrossRef]

75. Danish, R.Q.; Khalid Khan, M.; Shahid, A.U.; Raza, I.; Humayon, A.A. Effect of intrinsic rewards on task performance of employees: Mediating role of motivation. Int. J. Organ. Leadersh. 2015, 4, 33-46. [CrossRef]

76. Karanika-Murray, M.; Duncan, N.; Pontes, H.M.; Griffiths, M.D. Organizational identification, work engagement, and job satisfaction. J. Manag. Psychol. 2015, 30, 1019-1033. [CrossRef]

77. Preacher, K.J.; Hayes, A.F. SPSS and SAS procedures for estimating indirect effects in simple mediation models. Behav. Res. Methods Instrum. Comput. 2004, 36, 717-731. [CrossRef]

78. Yzerbyt, V.; Muller, D.; Batailler, C.; Judd, C.M. New recommendations for testing indirect effects in mediational models: The need to report and test component paths. J. Pers. Soc. Psychol. 2018, 115, 929. [CrossRef]

79. Eneizan, B.M.; Matar, A.; Al-Zawahreh, A.; Alkhawaldeh, A.M.; Eneizan, O. Effects of green marketing strategy on firm financial performance. The moderating role of government policy. Bus. Econ. Horiz. (BEH) 2019, 15, 304-324.

80. Martínez, P.; Herrero, Á.; Gómez-López, R. Corporate images and customer behavioral intentions in an environmentally certified context: Promoting environmental sustainability in the hospitality industry. Corp. Soc. Responsib. Environ. Manag. 2019, 26, 1382-1391. [CrossRef] 
81. De Oliveira, C.P.; Sousa, B.M. Green consumer behavior and its implications on brand marketing strategy. In Green Marketing as a Positive Driver toward Business Sustainability; IGI Global: Hershey, PA, USA, 2020; pp. 69-95.

82. Setyawati, H.; Suroso, A.; Adi, P.; Helmy, I. Linking green marketing strategy, religiosity, and firm performance: Evidence form Indonesian SMEs. Manag. Sci. Lett. 2020, 10, 2617-2624. [CrossRef]

83. Chuah, S.H.W.; El-Manstrly, D.; Tseng, M.L.; Ramayah, T. Sustaining customer engagement behavior through corporate social responsibility: The roles of environmental concern and green trust. J. Clean. Prod. 2020, 262, 121348. [CrossRef]

84. Preziosi, M.; Tourais, P.; Acampora, A.; Videira, N.; Merli, R. The role of environmental practices and communication on guest loyalty: Examining EU-Ecolabel in Portuguese hotels. J. Clean. Prod. 2019, 237, 117659. [CrossRef]

85. Amoako, G.K.; Dzogbenuku, R.K.; Abubakari, A. Do green knowledge and attitude influence the youth's green purchasing? Theory of planned behavior. Int. J. Prod. Perform. Manag. 2020, 69, 1609-1626. [CrossRef]

86. Chen, H.C.; Yang, C.H. Applying a multiple criteria decision-making approach to establishing green marketing audit criteria. J. Clean. Prod. 2019, 210, 256-265. [CrossRef]

87. Ting, C.T.; Hsieh, C.M.; Chang, H.P.; Chen, H.S. Environmental consciousness and green customer behavior: The moderating roles of incentive mechanisms. Sustainability 2019, 11, 819. [CrossRef]

88. Mahmoud, T.O.; Ibrahim, S.B.; Ali, A.H.; Bleady, A. The influence of green marketing mix on purchase intention: The mediation role of environmental knowledge. Int. J. Sci. Eng. Res. 2017, 8, 1040-1048. [CrossRef]

89. Nekmahmud, M.; Fekete-Farkas, M. Why not green marketing? Determinates of consumers' intention to green purchase decision in a new developing nation. Sustainability 2020, 12, 7880. [CrossRef]

90. Tarabieh, S.M.Z.A. Impact of Green Product Quality and Green Corporate Image on Green Customer Loyalty: Mediating Role of Green Customer Satisfaction. In Proceedings of the 4th International Congress on Social and Economic Sciences (ICSES), Budapest, Hungary, 26-30 November 2018; pp. 1-15.

91. Ranjan, R.K.; Kushwaha, R. Impact of Green Marketing Strategies on Consumer Purchase Behaviour. Rev. Manag. 2017, 7, 9-22.

92. Mahmoud, T.O. Impact of green marketing mix on purchase intention. Int. J. Adv. Appl. Sci. 2018, 5, 27-135. [CrossRef]

93. Vilkaite-Vaitone, N.; Skackauskiene, I. Green marketing orientation: Evolution, conceptualization and potential benefits. Open Econ. 2019, 2, 53-62. [CrossRef]

94. Liao, Y.K.; Wu, W.Y.; Pham, T.T. Examining the moderating effects of green marketing and green psychological benefits on customers' green attitude, value and purchase intention. Sustainability 2020, 12, 7461. [CrossRef]

95. Taherdangkoo, M.; Mona, B.; Ghasemi, K. The role of industries' environmental reputation and competitive intensity on sustainability marketing strategy: Customers' environmental concern approach. Span. J. Mark. -ESIC 2019, 23, 3-24. [CrossRef] 